\title{
DAILY COURSE OF THE SOIL TEMPERATURE IN SUMMER IN CHOSEN ECOSYSTEMS OF SŁOWIŃSKI NATIONAL PARK, NORTHERN POLAND
}

\author{
Ewa BeDNORZ, LesZeK KolENDOWICZ \\ Adam Mickiewicz University, Institute of Physical Geography and Environmental Planning, Poznań, Poland \\ Manuscript received January 21, 2010 \\ Revised version February 11, 2010
}

Bednorz E. \& Kolendowicz L., 2010. Daily course of the soil temperature in summer in chosen ecosystems of Słowiński National Park, northern Poland. Quaestiones Geographicae 29(1), Adam Mickiewicz University Press, Poznań 2010, pp. 5-12 , Figs 4. Tabs 4. ISBN 978-83-232-2136-4. ISSN 0137-477X. DOI: 10.2478/v10117-010-0001-X.

ABSTRACT. Patterns of the daily changes of the soil temperature in summer at three different ecosystems within the Słowiński National Park were analyzed. Strong correlation between the solar radiation and the soil temperature was found, particularly for the bare sandy surfaces, while the plant and humus cover hampers the solar energy flux to the soil. In the same way, correlations between the temperature of soil surface and the air temperature were computed. Finally, logarithmic models for the relationship between the global solar radiation and the soil surface temperature and between the soil surface temperature and the air temperature were constructed.

KEYWORDS: soil temperatures, correlation, Słowiński National Park, Baltic Sea coast.

Ewa Bednorz, Leszek Kolendowicz, Adam Mickiewicz University, Institute of Physical Geography and Environmental Planning, Dzięgielowa 27, 61-680 Poznań, Poland, ewabedno@amu.edu.pl, leszko@amu.edu.pl

\section{Introduction}

The exchange of energy between the atmosphere and the earth's surface significantly contributes to the development of the boundary layer climate. The primary source of this energy is solar radiation and the rate of the energy exchanges between the air and earth strongly depends on the amount of heat absorbed by the earth surface. The latter is affected by atmospheric factors, mainly cloud cover and circulation, on the one hand and by the soil structure and moisture on the other hand. The heat absorbed by the earth surface is partly transferred to the air and partly conducted into the deeper ground layers. Conduction is an extensive process, due to high specific heat capacity of the most kinds of soils. Thus, the ground becomes a kind of the heat storage for the lowest boundary layer (Paszyński et al., 1999). Variations in the temperature of different soil layers influence the transfer of sensible and latent heat from the surface to the air and, in this way, they affect atmospheric boundary layer processes and regional circulation (Pan \& Mahrt, 1987; Peters-Lidard et al., 1998). Furthermore, the soil temperature influences the water content in the ground accelerating or delaying evaporation. Amount of heat in the ground regulates the soil respiration, meaning efflux of carbon dioxide to the atmo- 
sphere (Kane \& Vogel, 1992; Alvesag \& Jansson, 1997; Gaumont-Guay et al., 2006; Li et al., 2008).

The temperature of soil layers, being the effect of the surface heat budget, varies on the annual and daily time scale. Multi-annual temporal positive changes in soil temperature were detected in Hilton Experimental Site, Shropshire, UK (Subedi \& Fullen, 2009) and in northern United States (Hu \& Feng, 2003). These findings contribute to evidences of global warming.

The soil temperature being of great significance for the growth and productivity of crops, is often analyzed in agricultural studies (Kaspar \& Bland, 1992; Wraith \& Ferguson, 1994; Bollero et al., 1996; Mungay et al., 1998). Growth of natural plant communities is also conditioned by thermal and hydrological characteristics of the soil (Keryn et al., 2004; Bond-Lamberty et al., 2005). Therefore, specific and unique ecosystems within the Słowiński National Park (SPN) on the Łeba Sandbar (southern coast of the Baltic Sea) were chosen for the study of thermal soil conditions during the vegetation period. The Łeba Sandbar is exceptional in many respects. Geomorphologically, it is built of quartz sand, which forms moving dunes in the central part of the bar, which are unique on the European scale. The barren sandy soil and deep level of ground water in the most of the Eeba Sandbar provide suitable growth conditions for specific natural plant communities, which are rare in European Lowlands. Owing to all these characteristics, the SPN has been included in the World Heritage List and the list of the nature reserves protected by the Ramsar Convention. The distinctive features of the earth surface occurring in the SPN result in the specific local topoclimatic conditions (Bednorz et al., 2001; Kolendowicz, 2002). The aim of this study is to approximate the role played by the active surface in the energy exchange and in shaping the climate of the lowest boundary layer called the surface layer (or the inner layer) of the atmosphere.

\section{Observation data and methods}

Research referred to in this work was carried out on behalf of the Field Station of the Climatology Department of Adam Mickiewicz University (AMU) located in the SPN. The station is based in the mid-length of the Łeba Sandbar, $10 \mathrm{~km}$ west of Łeba, at the distance of several dozen metres from the sea. The measurements elaborated in this study were conducted during three summer seasons (2003-2004, months of July and August).

The physiographic properties (topographic and geomorphological characteristics and the vegetation cover) affecting the character of the ground on the Łeba Sandbar are arranged in stripes parallel to the sea-line. Soil temperature was measured at three sites located in different zones. The first one (1) was situated on the bare sandy surface of the frontal dune. Due to its poor vegetation, this belt is referred to as a white sandy dune, occasionally reinforced with high grass. Behind the frontal dune embankment is a zone of topographic lows with a different cover and of a different colour. It is called a grey dune having the surface covered with grey lichens, low grass and sedge, which composes Helichryso-Jasionetum community. The second measurement site (2) was located there, covered mainly by lichens of the subspecies Cladonia and the grass Corynphorus canescens. The soil in the second site can be classified as initial soil, of loose structure with a very thin layer (less than $1 \mathrm{~cm}$ ) of dark humus. A pine forest (Empetro nigri-Pinetum typicum) makes the next zone, where the third measurement site (3) was located. Leached soil was identified at this site, which is covered with a moss layer (common forest mosses) and surrounded by dwarf shrubs of Empetrum nigrum, Calluna vulgaris, Vaccinum vitis-idaea and Carex arenaria (Mocek, 1997; Piotrowska, 1997a, 1997b). The measurement point was shaded during the day by the surrounding pine trees.

The soil temperature measurements were taken every hour at the depth of $0 \mathrm{~cm}, 5 \mathrm{~cm}, 10 \mathrm{~cm}$, $20 \mathrm{~cm}$ and $50 \mathrm{~cm}$ during three summer seasons (July, August, 2003 - 2005). Additionally, hourly measurements of the air temperature in the standard meteorological conditions ( $2 \mathrm{~m}$ above ground level in the instrument shelter) and hourly values of the global solar radiation intensity were used in this study. Measurements as well as the further analysis were carried out according to the legal summer time, meaning the East European time, which is approximately one hour later than the local time. Some other meteorological measurements and observations, taken at the Field Sta- 
tion of the Climatology Department AMU, were also considered in the study, with the purpose to identify the days with radiation weather and with cloudy, wet weather. The days with radiation weather are characterized by small cloudiness and low wind velocity. The energy and heat flux is the most intense on radiation days, therefore the topoclimatic characteristics of the particular ecosystems are the most distinctive in radiation conditions (Paszyński et al., 1999). Days with cloudy weather and with precipitation exceeding $1 \mathrm{~mm}$ were analyzed separately and they are referred to as the wet weather days in the further part of the study. The soil temperature descriptions were provided separately for each category of days as well as for an average day. Furthermore, in order to recognize the heat flux at the boundary layer, correlations between the solar radiation and the soil temperature were calculated, separately for different weather conditions. In the same way, correlations between the temperature of the soil surface and the air temperature were computed. An attempt was made to find a general model for the relationship between the global solar radiation and the soil surface temperature and between the soil surface temperature and the air temperature.

\section{Results}

The daily course of the soil temperature and the energy flux in deeper soil layers were different for the selected measurement sites and they strongly depended on the weather conditions, which determined the amount of the solar radiation energy supplied. The highest values of the soil temperature were observed during the radiation weather (compare thermoizopleths in Figs 1 and 2). Shortly after the sunrise (from 7:00), rapid heating of the surface was observed in such weather conditions. At measurement sites 1 and 2 , the mean surface temperature exceeded $28^{\circ} \mathrm{C}$, with the instantaneous values amounting to more than $35^{\circ} \mathrm{C}$. On the white dune (1) the thermal maximum was observed averagely at 13:00 of legal time (meaning the local noon) and on the grey dune, it was delayed to 14:00. In the pine forest (3), which was deprived of the direct solar radiation by the shading trees, the maximum values of surface temperature reached $20^{\circ} \mathrm{C}$ at $15: 00$. At the same timeframe, the highest values of the vertical gradient, counted as the difference between the temperature at the depth of $50 \mathrm{~cm}$ and $0 \mathrm{~cm}$, were observed (amounting to $-10^{\circ} \mathrm{C}$ at site 1 and 2 and $-7^{\circ} \mathrm{C}$ at site 3$)$. The delay in reaching the temperature maximum at site 2 and 3 indicates the influence of the plant and humus cover, which disturbs the solar energy flux to the soil.

Shortly after the maximal temperature is reached, rapid cooling of the soil surface occurs until the late evening, when the outgoing longwave radiation diminishes and the surface temperature changes slowly. The cooling proceeds

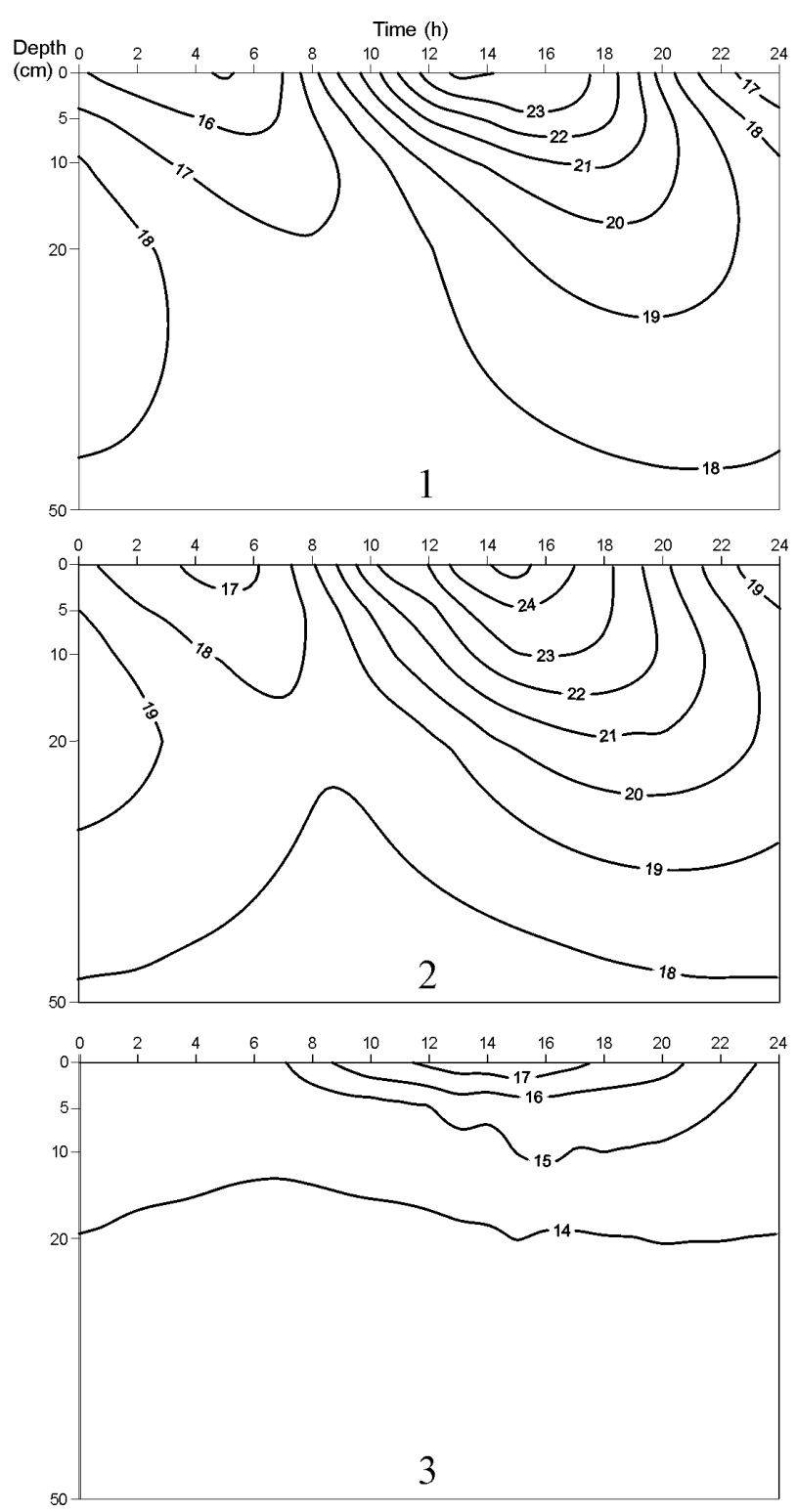

Fig. 1. Daily changes of the soil temperature. Thermoizopleths in ${ }^{\circ} \mathrm{C}$ constructed for all measurement days. 1,2,3 - sites of measurements 


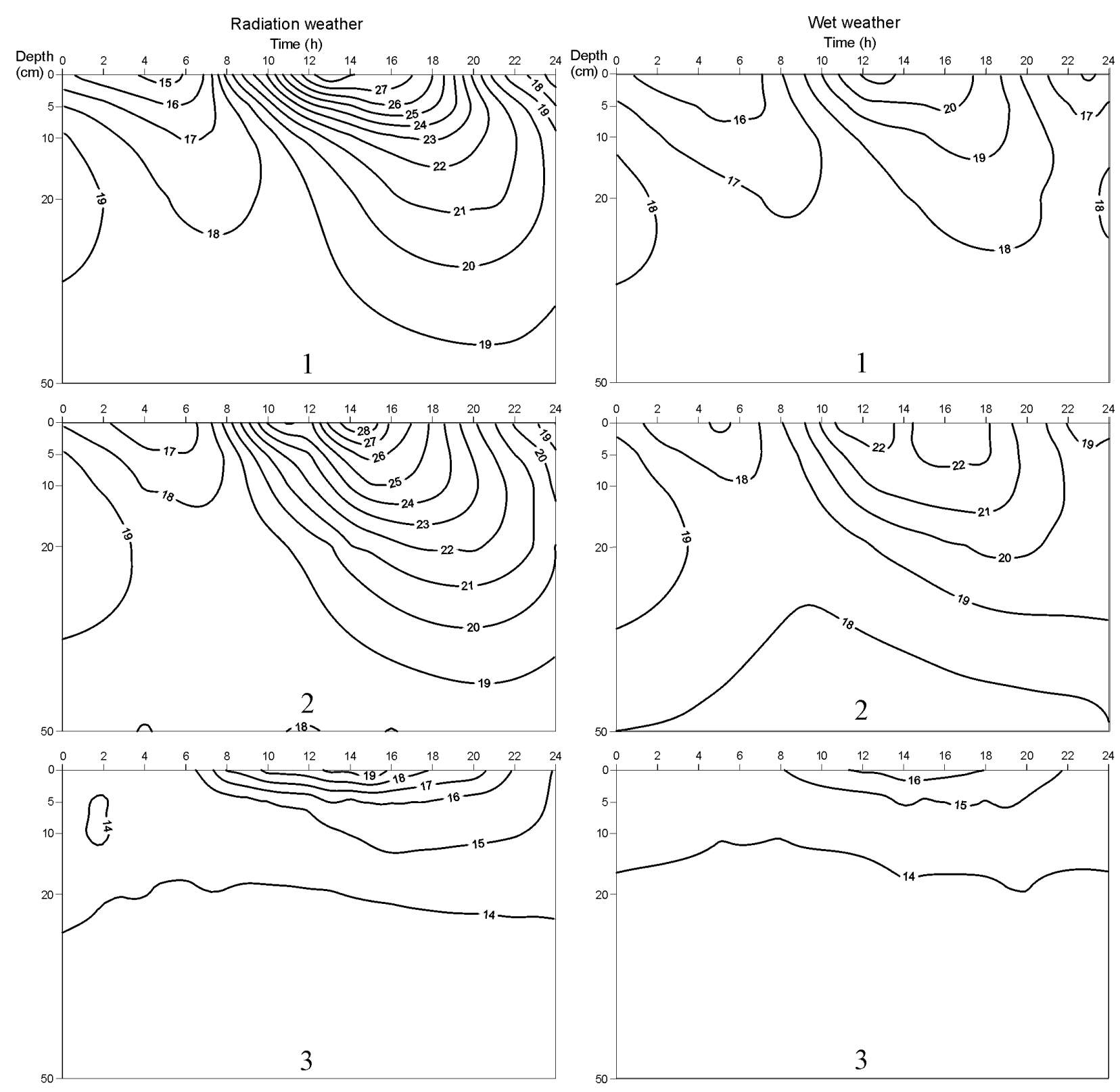

Fig. 2. Daily changes of the soil temperature. Thermoizopleths in ${ }^{\circ} \mathrm{C}$ constructed separately for different kinds of weather. $1,2,3$ - sites of measurements

most rapidly at the bare surface of the sand at site 1 (Fig. 2). The minimum of the soil surface temperature occurs at about 5:00, its value dropping below $15^{\circ} \mathrm{C}$ on the white dune (1) and amounting to $16.1^{\circ} \mathrm{C}$ on the grey dune (2). The ground surface in the pine forest (3) is the coolest both during the day and during the night, reaching the minimal temperature value of $14.1^{\circ} \mathrm{C}$.

Temperature extremes at lower layers of the soil occur later than the extremes at the surface, according to the third Fourier's law of thermal conduction. It was determined empirically that at the depth of $5 \mathrm{~cm}$ the delay amounts to 1 hour and respectively 2 hours at $10 \mathrm{~cm}, 4$ hours at 20 $\mathrm{cm}$ and to about 8 hours at the depth of $50 \mathrm{~cm}$. Values of the maximal temperatures diminish with the depth, while the minimal values are higher at deeper layers. This influences the daily amplitudes, which diminish along with the depth of the layers (second Fourier's law) (Table 1).

Both the temperature values and the dynamics of their changes were much lower during the wet weather days (Fig. 2), when the global solar radiation was reduced. The surface of the grey dune was the warmest, with the temperature reaching $22.9^{\circ} \mathrm{C}$, while the temperature of 
Table 1. Mean daily amplitudes of temperature $\left({ }^{\circ} \mathrm{C}\right)$

\begin{tabular}{|c|c|c|c|c|c|c|c|c|c|}
\hline \multirow{2}{*}{$\begin{array}{c}\text { Depth } \\
(\mathrm{cm})\end{array}$} & \multicolumn{3}{|c|}{ Site 1 (white dune) } & \multicolumn{3}{c|}{ Site 2 (grey dune) } & \multicolumn{3}{c|}{ Site 3 (pine forest) } \\
\cline { 2 - 11 } & $\begin{array}{c}\text { All } \\
\text { days }\end{array}$ & $\begin{array}{c}\text { Radiation } \\
\text { weather }\end{array}$ & $\begin{array}{c}\text { Wet } \\
\text { weather }\end{array}$ & $\begin{array}{c}\text { All } \\
\text { days }\end{array}$ & $\begin{array}{c}\text { Radiation } \\
\text { weather }\end{array}$ & $\begin{array}{c}\text { Wet } \\
\text { weather }\end{array}$ & $\begin{array}{c}\text { All } \\
\text { days }\end{array}$ & $\begin{array}{c}\text { Radiation } \\
\text { weather }\end{array}$ & $\begin{array}{c}\text { Wet } \\
\text { weather }\end{array}$ \\
\hline 00 & 9.4 & 14.4 & 6.4 & 8.9 & 12.6 & 6.2 & 3.7 & 6.0 & 2.5 \\
\hline 05 & 7.1 & 9.9 & 4.6 & 6.7 & 9.3 & 4.6 & 1.5 & 2.3 & 1.1 \\
\hline 10 & 4.8 & 6.3 & 3.1 & 5.4 & 7.4 & 3.7 & 1.2 & 1.9 & 0.8 \\
\hline 20 & 2.7 & 3.6 & 1.8 & 2.9 & 3.9 & 2.1 & 0.4 & 0.5 & 0.6 \\
\hline 50 & 0.4 & 0.5 & 0.6 & 0.4 & 0.6 & 1.0 & 0.2 & 0.5 & 0.5 \\
\hline
\end{tabular}

the bare sand surface at site 1 amounted to about $21^{\circ} \mathrm{C}$. The soil surface in the pine forest was definitely the coolest, with the maximal temperature hardly reaching $16.5^{\circ} \mathrm{C}$. The temperature of the leached soil at site 3 did not change much during wet weather days, with the amplitude amounting to $2.5^{\circ} \mathrm{C}$ at the surface and below $1^{\circ} \mathrm{C}$ at deeper layers. At other sites ( 1 and 2$)$, the daily amplitudes in the wet weather days were lower than the ones computed for the radiation days, and they reached about $6^{\circ} \mathrm{C}$ at the surface. Similarly to the radiation days, the thermal maximum on the white dune (1) was observed at about local noon and at the two others sites (2 and 3 ) it was delayed to 15.00 . The vertical gradient of the temperature in the afternoon hours was about half of its value during the radiation days $\left(-4.3^{\circ} \mathrm{C},-5.4^{\circ} \mathrm{C}\right.$ and $-3.8^{\circ} \mathrm{C}$ respectively at the 1,2 and 3 site). Although during the wet weather days the soil surface was relatively cold, it was slightly warmer in the night hours than during the radiation weather (by about $1^{\circ} \mathrm{C}$ at site 1 ).

The soil temperature is a measure of the amount of heat absorbed by the ground, mainly from the solar radiation. In order to determine the influence of the solar radiation intensity on the heat flux to the earth's surface, the correlation coefficients $(r)$ between the global solar radiation and the soil surface temperature at different weather conditions were computed. It was found out empirically that the maximum of the soil surface temperature usually occurs one hour later than the maximum of the global solar radiation intensity. Consequently, soil surface temperatures delayed by one hour were used for the purpose of the aforementioned computing. The highest values of correlation coefficients were obtained for the days with the radiation weather, when the largest amounts of solar energy are supplied (Table 2). For the grey dune $r=0.725$, which means that the intensity of the global solar radiation explains the variance of soil surface temperature in more than $50 \%$ (regression $r^{2}=$ 0.525). Distinctly lower correlation coefficients were computed for days with the wet weather: consequently, the influence of the solar radiation is reduced to $23-32 \%\left(r^{2}=0.312\right.$ for site 1 and $r^{2}=$ 0.234 for site 2). Among the three measurement sites, the lowest correlation between the global solar radiation and the soil surface temperature was found at site 3 . The intensity of the global solar radiation explains the variance of soil surface temperature in the pine forest only in about $11 \%\left(\mathrm{r}^{2}=0.116\right.$ for all days $)$ and it seems to have no direct impact during the days with the wet weather. Linear equations were constructed to explain the relationship between the intensity of the global solar radiation and soil surface temperature. The model applied to site 1 is shown in Fig. 3. The $\mathrm{R}^{2}$ coefficient amounts to 0.46 which means that the model explains the aforementioned relationship in $46 \%$.

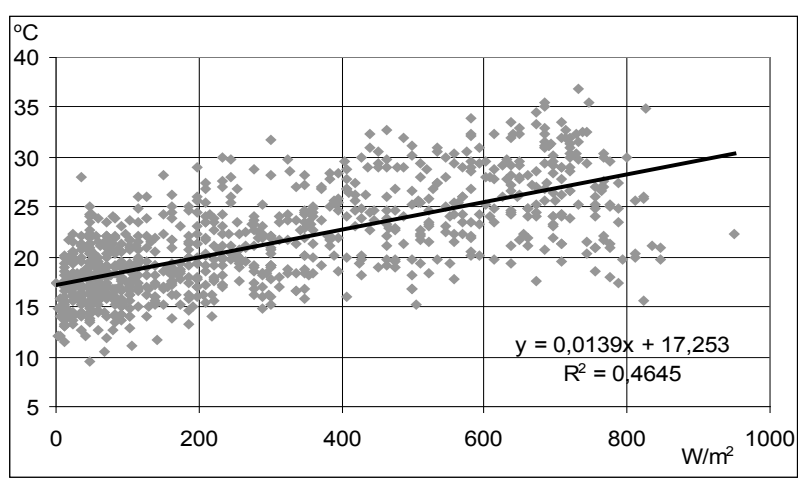

Fig. 3. The relationship between the intensity of global solar radiation and soil surface temperature at the measurement site 1 (white dune). Equation of the linear model is given. 
The energy absorbed by the earth surface is partly transferred to the air and partly conducted into the deeper ground layers. Therefore, the next step was computing of the correlation coefficients between the soil surface temperature and the air temperature at $2 \mathrm{~m}$ above ground level. High values, similar for both kinds of weather and for all measurement sites, were obtained $(r>0.82$, statistically significant at $99.9 \%$, Table 3 ). This means that the soil temperature explains the variance of the air temperature in more than $67 \%$. This time, the strongest correlation was observed at site 3, particularly during the wet weather $(r=0.913)$. Again, equations were constructed to account for the relationship between the soil surface temperature and the air temperature. For all sites, the logarithmic model is best suitable for the determination of the relation between the soil and air temperature. However, regressions of the linear models computed for the same relationship are not much lower (Fig. 4).

TABle 2. Correlation COEFFicients (R) BETWEEN THE GLOBAL SOLAR RADIATION AND THE SURFACE SOIL TEMPERATURE

\begin{tabular}{|c|c|c|c|}
\hline Site & $\begin{array}{c}\text { All } \\
\text { days }\end{array}$ & $\begin{array}{c}\text { Radiation } \\
\text { weather }\end{array}$ & $\begin{array}{c}\text { Wet } \\
\text { weather }\end{array}$ \\
\hline 1 (white dune) & 0.682 & 0.725 & 0.559 \\
\hline 2 (grey dune) & 0.653 & 0.673 & 0.484 \\
\hline 3 (pine forest) & $\mathbf{0 . 3 4 1}$ & $\mathbf{0 . 3 4 4}$ & 0.157 \\
\hline
\end{tabular}

Values statistically significant at $99.9 \%$ in bold.

Table 3. Correlation coefficients (R) BetweEn the SOIL SURFACE TEMPERATURE AND THE AIR TEMPERATURE AT $2 \mathrm{M}$ ABOVE GROUND LEVEL

\begin{tabular}{|c|c|c|c|}
\hline Site & $\begin{array}{c}\text { All } \\
\text { days }\end{array}$ & $\begin{array}{c}\text { Radiation } \\
\text { weather }\end{array}$ & $\begin{array}{c}\text { Wet } \\
\text { weather }\end{array}$ \\
\hline 1 (white dune) & 0.856 & 0.859 & 0.862 \\
\hline 2 (grey dune) & 0.826 & 0.852 & 0.820 \\
\hline 3 (pine forest) & 0.890 & 0.878 & 0.913 \\
\hline
\end{tabular}

All values statistically significant at $99.9 \%$.

Finally, the conduction of heat to the deeper layers of soil was estimated by computing correlation coefficients between the surface soil temperature and the soil temperature at lower depths. Heat conduction in sandy soil is an extensive
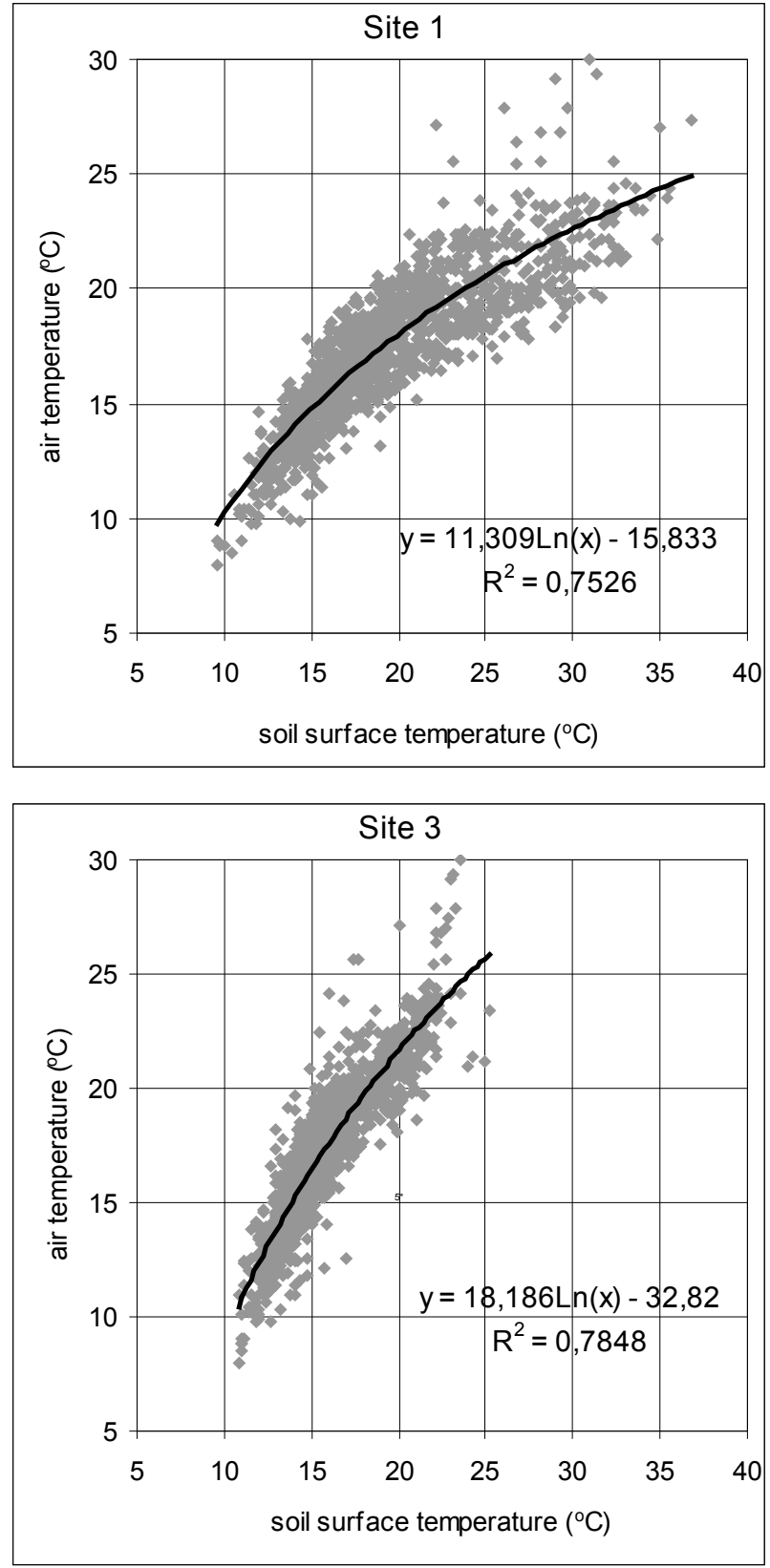

Fig. 4. The relationship between the soil surface temperature and the air temperature at the measurement site 1 (white dune) and 3 (pine forest). Equations for logarithmic models are given.

process, due to the high specific heat capacity of quartz sand. Therefore, the delay of the temperature extremes increases along with the increasing depth and it amounts to 1 hour at the depth of 5 $\mathrm{cm}$, to 2 hours at the depth of $10 \mathrm{~cm}$, to 4 hours at the depth of $20 \mathrm{~cm}$ and to approximately 8 hours at the depth of $50 \mathrm{~cm}$. Delayed temperatures of consecutive soil layers were correlated with the soil surface temperatures (Table 4). The correlation coefficient computed for the wet weather days is statistically significant ( $p=99 \%$ ) along the whole 
Daily course of the soil temperature in summer in chosen ecosystem of SŁowiński National Park...

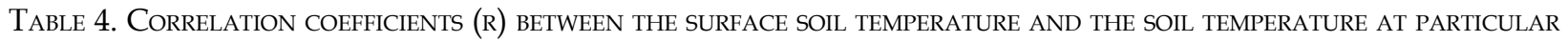
DEPTHS

\begin{tabular}{|c|c|c|c|c|c|c|c|c|c|}
\hline \multirow{2}{*}{$\begin{array}{c}\text { Depth } \\
\text { (cm) }\end{array}$} & \multicolumn{3}{|c|}{ Site 1 (white dune) } & \multicolumn{3}{c|}{ Site 2 (grey dune) } & \multicolumn{3}{c|}{ Site 3 (pine forest) } \\
\cline { 2 - 10 } & $\begin{array}{c}\text { All } \\
\text { days }\end{array}$ & $\begin{array}{c}\text { Radiation } \\
\text { weather }\end{array}$ & $\begin{array}{c}\text { Wet } \\
\text { weather }\end{array}$ & $\begin{array}{c}\text { All } \\
\text { days }\end{array}$ & $\begin{array}{c}\text { Radiation } \\
\text { weather }\end{array}$ & $\begin{array}{c}\text { Wet } \\
\text { weather }\end{array}$ & $\begin{array}{c}\text { All } \\
\text { days }\end{array}$ & $\begin{array}{c}\text { Radiation } \\
\text { weather }\end{array}$ & $\begin{array}{c}\text { Wet } \\
\text { weather }\end{array}$ \\
\hline 00 & $\mathbf{1 . 0 0 0}$ & $\mathbf{1 . 0 0 0}$ & $\mathbf{1 . 0 0 0}$ & $\mathbf{1 . 0 0 0}$ & $\mathbf{1 . 0 0 0}$ & $\mathbf{1 . 0 0 0}$ & $\mathbf{1 . 0 0 0}$ & $\mathbf{1 . 0 0 0}$ & $\mathbf{1 . 0 0 0}$ \\
\hline 05 & $\mathbf{0 . 9 5 4}$ & $\mathbf{0 . 9 4 4}$ & $\mathbf{0 . 9 4 8}$ & $\mathbf{0 . 9 7 0}$ & $\mathbf{0 . 9 7 4}$ & $\mathbf{0 . 9 4 9}$ & $\mathbf{0 . 7 9 8}$ & $\mathbf{0 . 7 4 1}$ & $\mathbf{0 . 8 4 6}$ \\
\hline 10 & $\mathbf{0 . 8 9 2}$ & $\mathbf{0 . 8 4 7}$ & $\mathbf{0 . 9 0 1}$ & $\mathbf{0 . 9 4 8}$ & $\mathbf{0 . 9 4 9}$ & $\mathbf{0 . 9 1 5}$ & $\mathbf{0 . 7 0 4}$ & $\mathbf{0 . 5 5 1}$ & $\mathbf{0 . 7 8 1}$ \\
\hline 20 & $\mathbf{0 . 7 9 3}$ & $\mathbf{0 . 7 3 7}$ & $\mathbf{0 . 7 9 5}$ & $\mathbf{0 . 8 4 0}$ & $\mathbf{0 . 8 3 0}$ & $\mathbf{0 . 8 1 3}$ & $\mathbf{0 . 6 1 7}$ & $\mathbf{0 . 4 4 6}$ & $\mathbf{0 . 6 2 9}$ \\
\hline 50 & $\mathbf{0 . 4 9 2}$ & 0.292 & $\mathbf{0 . 5 4 5}$ & $\mathbf{0 . 5 1 0}$ & $\mathbf{0 . 4 1 2}$ & $\mathbf{0 . 4 9 5}$ & $\mathbf{0 . 4 3 2}$ & 0.227 & $\mathbf{0 . 3 7 4}$ \\
\hline
\end{tabular}

Values statistically significant at $99.9 \%$ in bold.

vertical profile at all measurement sites. During the radiation weather, when the heat flux is very intensive, sandy soils of the white dune (1) and the grey dune (2) accumulate a lot of energy, which is transported slowly in the dry sand to deeper layers. Temperature at the depth of $50 \mathrm{~cm}$ is weakly correlated with the surface temperature at sites 1 and 2 during days with radiation weather. In the pine forest (site 3) the heat transport to the lower layers of soil seems to be least intensive. Correlation coefficients between the surface temperature and the temperature at lower depths are weaker than at two other sites. The diurnal heat transfer hardly reaches the lowest layer of $50 \mathrm{~cm}$ under ground level, where the average daily amplitude of temperature amounts to $0.2^{\circ} \mathrm{C}$ and where the weakest relationships with the temperature of the surface were found at both types of weather condition on the daily timescale (Table 4).

\section{Discussion and conclusions}

Patterns of the daily changes of the soil temperature, recognized at three different ecosystems in the SNP during three summer seasons are in conformity with the Fourier laws of conduction, namely: 1) the daily cycle of the temperature changes is constant in the whole soil profile, 2) daily amplitudes diminish along with the depth of the layers, 3) the temperature extremes at lower soil layers are delayed in comparison with the temperature extremes at the surface, (the quantity of the delay was determined empirically in the study). Although the general rules are followed at each selected measurement site, there are differences in the daily course of the soil temperature between various surfaces and between various weather conditions, which determine the amount of the supplied solar radiation energy.

The soil temperature is a measure of the amount of heat absorbed by the ground from the solar radiation and it depends on the specific heat capacity and conduction of the soil. The delays in reaching the temperature maximum observed at sites 2 and 3, which are covered with plants, in comparison with the bare sands of the white dune (site 1), point to the influence of the plant and humus cover, which hampers the solar energy flux to the soil. Similar thermal conditions of the eolian sands at the Łeba Sandbar were described by Rabski (1984).

In the pine forest, deprived of the direct solar radiation and with a considerable amount of the solar energy absorbed by tree crowns, soil surface temperatures take on the lowest values, which are most often below the values of the air temperatures. In addition, they are weakly correlated with the global solar radiation. This implies a reverse heat flux direction, i.e. from the air to the ground. Similar conclusions were reached by Bednarek (1966), who has investigated the relationships between soil surface temperatures and air temperatures in the Białowieża National Park. Keryn et al. (2004) using a simple model for predicting soil temperature at the basis of daily air temperature and its amplitude, explained $88 \%$ of the variation in average daily soil temperature under forests in Australia. Bond-Lamberty (2005) applied segmented linear model of the relationship between the air and soil temperature in boreal forests throughout a year. The relationship changed at the breakpoint 
temperature of $-1-2^{\circ} \mathrm{C}$. For the negative air temperatures the trend line was horizontal and for positive air temperatures a steeper trend line was obtained, similarly to results obtained in this paper (see Fig. 4). More advanced mathematical model based on Haar wavelets was applied by Hariharan et al. (2009) to estimate depth profile $(0-45 \mathrm{~cm})$ of soil temperature in Trombay (India).

Different patterns of the daily soil temperature fluctuations, analyzed in this paper, are observed for two different weather types: the radiation weather and wet weather, particularly for the sandy soils of white and grey dune. During the radiation weather days, the temperature changes are more dynamic and the daily amplitudes at each depth are much higher than on the wet weather days. The higher wind speed during the non-radiation days may be considered as an additional factor reducing the heat transfer to the soil (Mungai et al., 1998). In the pine forest, the differences between the soil temperature during the radiation weather and wet weather are not so significant, however, on the wet weather days, hardly any temperature changes under the surface are observed.

Models representing the relationships between the soil surface temperature and the intensity of global solar radiation and between the soil surface temperature and the air temperature, used in this study, show that the aforementioned relationships are very strong thus allowing the possibility of predicting both the temperature of the soil surface and the temperature of the surface layer of the atmosphere.

\section{References}

Alvesag G. \& JAnsson P.E., 1997. Model for evaporation, moisture and temperature of bare soil: calibration and sensitivity analysis. Agricultural and Forest Meteorology 88: 47-56.

BEDNAREK A., 1966. O wpływie temperatury powietrza na kształtowanie temperatury gleby $\mathrm{w}$ warunkach ograniczonego dopływu energii promieniowania Słońca. Przegląd Geofizyczny 11(4): 251-260.

Bednorz E., Kolendowicz L. \& Szyga-Pluta K., 2001. Topoclimates of the part of Słowiński National Park. Dokumentacja Geograficzna PAN Warszawa 23: 19-31.

Bollero G.A., Bullock D.G. \& Hollinger S.E., 1996. Soil temperature and planting date effects on corn yield, leaf area, and plant development. Agronomy Journal 88: 385-390.

Bond-Lamberty B., WANG C. \& Gower S.T., 2005. Spatiotemporal measurement and modeling of stand-level boreal forest soil temperatures. Agricultural and Forest Meteorology 131: 27-40.
Gaumont-Guay D., Black T.A., Griffis T.J., Barra A.G., JASSAL R.S. \& NESIC Z.: 2006. Interpreting the dependence of soil respiration on soil temperature and water content in a boreal aspen stand. Agricultural and Forest Meteorology 140: 220-235.

Hariharan G., KanNan K. \& Sharma K.R., 2009. Haar wavelet in estimating depth profile of soil temperature. Applied Mathematics and Computation 210: 119-125.

Hu Q. \& FENG S., 2003. A daily soil temperature dataset and soil temperature climatology of the contiguous United States. Journal of Applied Meteorology 42: 1139-1156.

Kane E.S. \& Vogel J.G., 1992. Patterns of Total Ecosystem Carbon Storage with Changes in Soil Temperature in Boreal Black Spruce Forests. Ecosystems 12: 322-335.

KAsPaR T.C. \& Bland W.L., 1992. Soil temperature and root growth. Soil Scicience 154: 290-299.

Keryn I.P., Polglase P.J., Smethurst P.J., O'Connel A.M., CARYle C.J. \& Khana P.K., 2004. Soil temperature under forests: a simple model for predicting soil temperature under a range of forest types. Agricultural and Forest Meteorology 121: 167-182.

Kolendowicz L., 2002. Diel variation in air temperature, relative humidity and cooling power in Słowiński National Park. Badania Fizjograficzne nad Polską Zachodnia 53: 83-93.

Li H., YAN J., YUE X. \& WANG M., 2008. Significance of soil temperature and moisture for soil respiration in a Chinese mountain area. Agricultural and Forest Meteorology 148: 490-503.

MoceK A., 1997. Współczesne gleby leśne. In: H. Piotrowska (ed.): Przyroda Stowińskiego Parku Narodowego. Bogucki Wydawnictwo Naukowe, Poznań-Gdańsk: 77-94.

Mungai D.N., Stigter C.J., Coulson C.L. \& NG' ANG'A J.K., 1998. Simply obtained global radiation, soil temperature and soil moisture in an alley cropping in semi-arid Kenya. Theoretical and Applied Climatology 65: 63-78.

PAN H.L. \& MAHRT L., 1987. Interaction between soil hydrology and boundary layer development. Boundary-Layer Meteorology 38: 185-202.

PAszyński J., Miara K. \& SKoczeK J., 1999. Wymiana energii między atmosferą a podłożem jako podstawa kartowania topoklimatycznego. Dokumentacja Geograficzna 14: 1-127.

Peters-Lidard C.D., Blackburn E., Liang X. \& Wood E.F., 1998. The effect of soil thermal conductivity parameterization on surface energy fluxes and temperatures. Journal of the Atmospheric Sciences 55: 1209-1224.

Piotrowska H., 1997a. Lasy. In: H. Piotrowska (ed.): Przyroda Stowińskiego Parku Narodowego. Bogucki Wydawnictwo Naukowe, Poznań-Gdańsk: 157-196.

Piotrowska H., 1997b. Roślinność wydm. In: H. Piotrowska (ed.): Przyroda Stowińskiego Parku Narodowego. Bogucki Wydawnictwo Naukowe, Poznań-Gdańsk: 197-227.

RABSKI K., 1984. Eolian sands temperature conditions on the Łeba Bar. Sprawozdania PTPN 100: 170-173.

Subedi M. \& Fullen M.A., 2009. Temporal changes in soil temperature at the Hilton Experimental Site, Shropshire, UK (1982-2006): Evidence of a warming trend?. Archives of Agronomy and Soil Science 55, 105-113. 